\title{
Histology and Histochemistry of the Adrenal Gland African Giant Rat (Cricetomys gambianus, Waterhouse)
}

\author{
Histología e Histoquímica de la Glándula Adrenal de la Rata \\ Africana Gigante (Cricetomys gambianus, Waterhouse).
}

Samuel Gbadebo Olukole*; Mojibola Abosede Adeagbo* \& Bankole Olusiji Oke*

OLUKOLE, S. G.; ADEAGBO, M. A. \& OKE, B. O. Histology and histochemistry of the adrenal gland African giant rat (Cricetomys gambianus, Waterhouse). Int. J. Morphol., 34(4):1455-1460, 2016.

SUMMARY: The histology and histochemistry of the adrenal gland of the African giant rat, AGR (Cricetomys gambianus Waterhouse) was carried out using ten adult male rats with the knowledge of providing information which could be helpful in an improved knowledge of the structure and function of the gland. The adrenal gland of the African giant rat has a distinct cortex and medulla surrounded by a thin rim of capsule. The adrenal cortex has three zones which are basically the zona glomerulosa, zona fasiculata and zona reticularis with the absence of zona intermedia. The zona glomerulosa contains polyhedral cells which form irregular clusters or cords while the zona fasiculata had radial cells of cuboidal or polyhedral shape. The cells of zona reticularis are similar to those of the zona fasiculata and in addition contain small cells as irregular cords and clusters. The cells of the adrenal medulla are composed of irregular epithelioid cells arranged in rounded groups or short cords and are mostly columnar or polyhedral chromaffin cells which are separated by sinusoids. The adrenal capsule, cortex and medulla were Periodic Acid-Schiff-positive.The adrenal capsule and adrenal medulla was Masson Trichrome-positive unlike the zona fasiculata and zona reticularis. The adrenal capsule and zona glomerulosa were Verhoeff-positive unlike the other zones of the gland. In conclusion the histology of the adrenal gland of the AGR is similar to those of other mammals with a few exceptions, the entire gland is rich in carbohydrate while the capsule and by extension, the outermost portion of the cortex are rich in collagen and elastic fibers. The outcome of this research provides information needed in the better improved understanding of the structure and function of the adrenal gland of the animal.

KEY WORDS: Adrenal Gland; African Giant Rat; Cortex; Medulla.

\section{INTRODUCTION}

The African giant rat (Cricetomys gambianus, Waterhouse), is a wild rodent widely distributed in subSaharan Africa which has been reported to be fairly tame and docile in captivity (Oke \& Aire, 1989; Olude et al., 2010). The rodent is an important bush meat in Nigeria, being an alternative source of protein (Olude et al.). The gland is surrounded by an adipose capsule and is enclosed within the renal fascia, a fibrous structure that also surrounds the kidney (Moore et al., 2014). There are 2 parts actually: an adrenal cortex and an adrenal medulla. An appreciable number of anatomical research studies on the African giant rat had been reported by several authors. These include: some aspects of the reproductive biology of the male African giant rat (Oke, 1988); anatomy of the bulbourethral gland (Oke \& Aire, 1989); ultrastructure of the epididymis (Oke \& Aire, 1990); structure of the prostate glands (Oke \& Aire, 1990); characterization of the uterus and mammary glands of the female African giant rats (Akinloye \& Oke, 2010); macroanatomical investigations of the skeletons of the African giant rat (Olude et al., 2010); histology and histochemical studies of the colon in the African giant rat (Nzalak et al., 2011); macrometric study of the digestive system of the African giant rat (Nzalak et al., 2012); macro-anatomical studies of the axial skeletons of the African giant rat (Onwuama et al., 2013); ultrastructural features of the ovary of the female African giant rat (Akinloye \& Oke) and the olfactory bulb structure of African giant rat (Olude et al.) among others.

There is a dearth of information on the histological and histochemical features of the adrenal gland of the African giant rat. This study was therefore designed to investigate the histology and histochemistry of the adrenal gland of the African giant rat with the aim of providing useful information which could lead to an improved knowledge of the adrenal 
gland of the animal with respect to the hormones produced. Findings from the study apart from providing baseline data on the adrenal gland of the animal are expected to be useful in the comparative regional anatomy of the adrenal glands of rodents.

\section{MATERIAL AND METHOD}

Experimental Animals. Ten adult African giant rats captured directly from the wild were used for the study. The rats were kept at the African giant rat unit of the Animal House, Faculty of Veterinary Medicine, University of Ibadan. They were restrained with a towel soaked in chloroform on their faces to render them unconscious. They were weighed using the Microvar weighing balance after they have been rendered unconscious. They were sacrificed by cervical decapitation. The carcass was placed on a dissecting board on dorsal recumbency after which incision was made from the linea alba to the anal region thereby exposing the visceral organs. The kidneys were carefully harvested and the adrenal glands were removed from each kidney. The left and right adrenal glands were weighed prior to histological sample collection.

Histological Procedures. Samples of the adrenal glands were immediately fixed in $10 \%$ formalin solution and processed for Paraffin technique (Olukole et al., 2014). Special stains used were Masson's Trichrome (MT): to differentiate between collagen and smooth muscle; Periodic acid-Schiff (PAS): to demonstrate glycogen and neutral mucosubstances and Verhoeff's stain: to demonstrate normal or pathologic elastic fibers.

The slides were examined using the Light Microscope. Representative photographs of different sections of the adrenal gland of the animal were taken using a Gatan 785 Erlangshen digital camera (Gatan Inc., Warrendale, PA). Analysis and assembling of composite micrographs were carried out using Adobe Photoshop CS5 (Adobe Systems, San Jose, CA). Morphometric analyses of the gland were performed with the aid of GIMP 2 Software using five serial sections per animal, totaling 50 serial sections per parameter of the adrenal gland: thickness of adipose tissue layer and capsule, depth of cortex and medulla.

Statistical Analysis. All numeric data obtained were expressed as means with the standard error of mean using the GraphPad Prism version 4.00 for Windows, GraphPad Software. Analysis of variance was performed using the Student $\mathrm{T}$ Test and significance reported at $\mathrm{P}<0.05$.

\section{RESULTS}

The average weight of the rats used in the study was $623 \pm 1.10 \mathrm{~g}$. The means and standard error of means for various parameters of the adrenal gland are given in Table I. The relative adrenal weight (left and right) was $0.016 \%$. The left and right adrenal glands lay on the cranial end of their corresponding kidneys on each side of the vertebral column. The right adrenal gland was more cranially placed compared to the left. There was a significant difference $\mathrm{P}<0.05)$ between the weights of the left and right adrenal glands (Table I). There was also a significant difference $(\mathrm{P}<0.05)$ between the depths of the cortex and the medulla (Table I). The adrenal gland of the African giant rat is composed of an inner medulla region surrounded by a cortex which is rapped by a capsule with the capsule having an adipose tissue layer surrounding it (Fig. 1A). The adrenal gland is enclosed by a thick capsule of collagenous connective tissue that extends into the cortex to varying depths as trabeculae (Fig. 2). Features of the adipose tissue include blood vessels, unmylinated nerves, striated muscle fibers, capillaries and while epithelial cells are found in the capsule (Fig. 1B). The adrenal cortex of the AGR can be divided into three zones, from without--within order, the zones are: the zona glomerulosa, zona fasiculata and zona reticularis. The zona glomerulosa contains polyhedral cells which form irregular clusters or cords (Fig. 1C). Cells in this zone form ovoid groups, separated by trabeculae of connective tissue that are continuous with the fibrous capsule of the gland and are wide (Figs. 1B and C).

The zona fasiculata is situated between the zona glomerulosa and zona reticularis with no intermediate zone between them. It is the widest of the three layers of the adrenal cortex as it composes nearly $80 \%$ of the cortical tissue (Figs. 1B and C).. This zone is the widest with radial cells of cuboidal or polyhedral while cords of this zone are separated by sinusoids and the cytoplasm appears foamy due to the numerous lipid vacuoles (Figs. 1B and C). The zona fasiculata is made up of spongiocytes that are arranged in columns. The cytoplasm of the cells of the zona fasiculata contained numerous lipid droplets (Figs. 1B and C). The

Table I. Mean and SEM values of the parameters of the adrenal gland of the African giant rat (Cricetomys gambianus, Waterhouse).

\begin{tabular}{ccccccrr}
\hline WA $(\mathrm{g})$ & RAW $(\%)$ & WLA $(\mathrm{g})$ & WRA $(\mathrm{g})$ & ATT $(\mu \mathrm{m})$ & CPT $(\mu \mathrm{m})$ & CXD $(\mu \mathrm{m})$ & MDD $(\mu \mathrm{m})$ \\
\hline $623 \pm 1.10$ & 0.016 & $0.12 \pm 0.002^{\mathrm{a}}$ & $0.085 \pm 0.002 \mathrm{~b}$ & $109 \pm 4.3$ & $29 \pm 1.1$ & $507 \pm 24.0^{\mathrm{c}}$ & $380 \pm 13.0^{\mathrm{d}}$
\end{tabular}

Means with different superscripts within rows are statically significant $(\mathrm{P}<0.05)$. 
cells of the zona reticularis are irregularly arranged as anastomosing cords surrounded by sinusoids (Fig. 1D). Some cells of the zona reticularis are found projecting into the medulla. The cells of the adrenal medulla are composed of irregular epithelioid cells arranged in rounded groups or short cords and are mostly columnar or polyhedral chromaffin cells which are separated by sinusoids (Fig. 1D).

The adipose tissue and capsule of the adrenal gland and zona glomerulosa were MT positive with collagen and smooth muscles being the basic constituents of the capsule (Fig. 2A). However, the zona fasiculata and zona reticularis were MT- negative unlike the adrenal medulla (Fig. 2B). The adrenal capsule, the entire adrenal cortex and adrenal medulla were PAS-positive (Figs. $2 \mathrm{C}$ and D). The adipose tissue surrounding the adrenal gland showed a negative reaction with Verhoeff Stain, VS (Fig. 2E). The capsule was however VS-positive with distinct separation from the cortex (Fig. 2E). The zona glomerulosa is the only zone of the adrenal cortex that was VS-positive (Fig. 2F).

Table II. Summary of the reactions of different regions of the adrenal gland of the African giant rat to special stains.

\begin{tabular}{llll}
\hline Segment of gland & MT & PAS & VS \\
\hline Adipose tissue $\quad$ Collagen & + & + & - \\
Capsule $\quad$ Smooth muscle & ++ & ++ & + \\
Zona glomerulosa & + & + & - \\
Zona fasiculata & - & + & - \\
Zona reticularis & - & + & - \\
Andrenal medulla & + & + & - \\
\hline
\end{tabular}

MT: Masson's Trichrome; PAS: Periodic Acid-Schiff; VS: Verhoeff Stain.

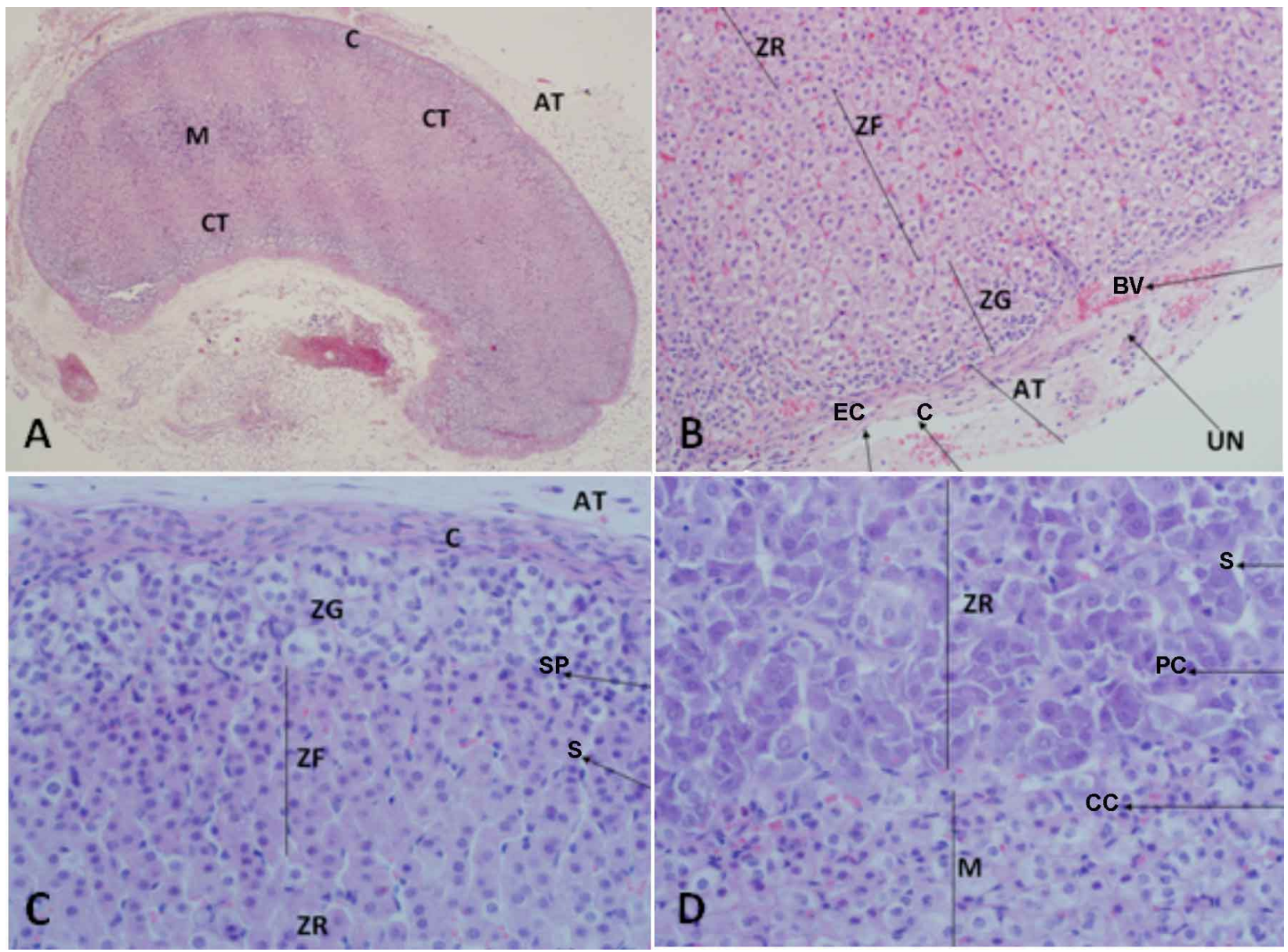

Fig. 1A. Photomicrograph of the adrenal gland of the African giant rat (Cricetomys gambianus) showing Adipose tissue: AT; Capsule: C; Cortex: CT; and Medulla: M. x40 (H\&E). Fig. 1B. Photomicrograph of the adrenal cortex of the African giant rat (Cricetomys gambianus). AT:Adipose Tissue; BV: Blood Vessel; C: Capillary; EC: Epithelial cells; UN: Unmyelinated Nerve; ZG: Zona Glomerulosa; ZF: Zona Fasiculata ZR: Zona Reticularis. X100 (H\&E). Fig. 1C. Photomicrograph of the adrenal cortex of the African giant rat (Cricetomys gambianus) showing Adipose tissue: AT; Capsule: C; Sinusoids: S; Spongiocyte: SP; Zona Glomerulosa: ZG; Zona Fasiculata: ZF and Zona Reticularis: ZR. X400 (H\&E). Fig. 1D. Photomicrograph of the adrenal gland of the African Giant Rat (Cricetomys gambianus) showing Chromaffin Cells: CC; Pigmented Cells: PC; Sinusoids: S; Medulla:M and Zona Reticularis: ZR. X 400 (H\&E). 

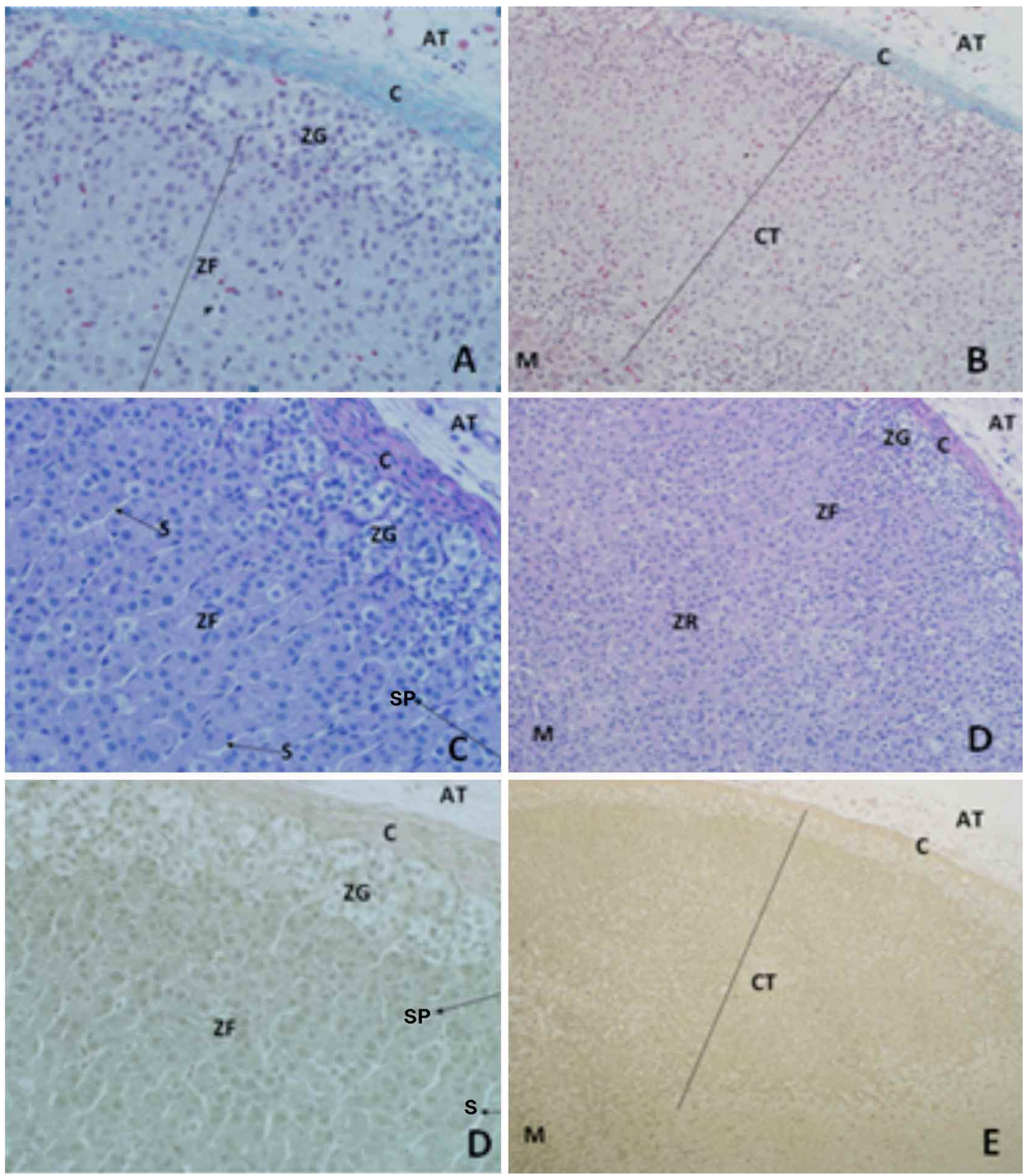

Fig. 2A. Photomicrograph of the adrenal cortex of the African giant Rat (Cricetomys gambianus) showing Adipose tissue: AT; Capsule: C; Zona Glomerulosa: ZG and Zona Fasiculata: ZF. X100 (MT). Fig. 2B. Photomicrograph of the adrenal gland of the African giant Rat (Cricetomys gambianus) showing Adipose tissue: AT; Capsule: C; Cortex: CT; and Medulla: M x40 (MT) Fig. 2C. Photomicrograph of the adrenal cortex of the African giant Rat (Cricetomys gambianus) showing Adipose tissue: AT; Capsule: C; Sinusoids: S; Spongiocyte: SP; Zona Glomerulosa: ZG and Zona Fasiculata: ZF.X400 (PAS). Fig. 2D. Photomicrograph of the adrenal gland of the African giant Rat (Cricetomys gambianus) showing Adipose tissue: AT; Capsule: C; Medulla: M; Zona Glomerulosa: ZG; Zona Fasiculata: ZF and Zona Reticularis: ZR. X100 (PAS). Fig. 2E. Photomicrograph of the adrenal cortex of the African giant Rat (Cricetomys gambianus) showing Adipose tissue: AT; Capsule: C; Sinusoids: S; Spongiocyte: SP; Zona Glomerulosa: ZG and Zona Fasiculata: ZF.X400 (VER). Fig. 2F. Photomicrograph of the adrenal gland of the African giant Rat (Cricetomys gambianus) showing Adipose tissue: AT; Capsule: C; Cortex: CT; and Medulla: M x40 (VER). 


\section{DISCUSSION}

The anatomical position and the relations of the adrenal gland of the AGR correspond to that reported in mammals (Onyeanusi et al., 2009; Olukole, 2009). The significance difference observed between weights of the left and right adrenal glands is similar to previous reports on paired organs of wild rodents (Oke; Olukole, 2009, Olukole et al., 2010). The histological features of the adipose tissue surrounding the adrenal capsule of the African giant rat are similar to those of other mammals (Bacha \& Bacha, 2000). The absence of a zona intermedia in between the zona glomerulosa and zona fasiculata in the African giant rat is at variant with what is obtained in carnivores, horses and bottlenose dolphins which have been reported to have four zones: zona glomerulosa, zona intermedia, zona fasiculata and zona reticularis (Banks, 1993; Dellmann, 1993; Bacha \& Bacha). The irregular clusters or cords pattern of arrangement of the polyhedral cells of the zona glomerulosa of the African giant rat does not conform to what is seen in most mammals. In the carnivore, horse, and pig, the parenchymal cells of the zona glomerulosa are columnar and arranged into arcs. In the horse the columnar cells are especially tall (Bacha \& Bacha). The zona fasiculata of the African giant rat conforms to those of previous reports being the widest of the three layers of the adrenal cortex comprising about $60-80 \%$ of the cortical tissue (Bacha \& Bacha; Junqueira \& Carneiro, 2005). The zona fasiculata has the widest radial cells of cuboidal or polyhedral with cords of this zone are separated by sinusoids (Vukovic et al., 2010). A gradual transition from zona fasiculata to zona reticularis with the cells of the zona reticularis having an irregular pattern of anastomosing cords surrounded by sinusoids is similar to previous reports in other mammals (Banks; Vukovic et al.). The columnar or polyhedral chromaffin cells of the adrenal medulla of the African giant rat which form clusters and anastomosing cords separated by sinusoids had also been reported in mammals (Bacha \& Bacha). Moreover, in horses, cows, sheep and pigs, the medulla is divided into two areas, the outer area, made up of the more intensively stained epinephrine- secreting cells, and the inner area, built of norepinephrine- secreting cells that have a weaker stain affinity (Dellmann). The absence of connective tissue separating the adrenal cortex and the medulla in the African giant rat is at variance with what obtains in the dolphins and harbor seal male (Clark et al., 2008).

The positive reactions of the adrenal capsule of the African giant rat with Masson's Trichrome, Periodic Acid Schiff and Verhoeff stain imply that the capsule is rich in collagen, carbohydrate and elastic fibers, respectively. The zona glomerulosa of the African giant rat, being positive with Periodic Acid Schiff and Verhoeff stain implies that the zone is rich in carbohydrate and possesses some elastic fibers. This is probably due to the penetration of the trabeculae from the adrenal capsule into the zona glomerulosa. The negative reaction of the zona fasiculata with Verhoff stain implies that the zone is devoid of elastic fibers while its positive reaction with Periodic Acid Schiff shows that the zone is rich in carbohydrate. The positive reaction of the adrenal medulla of the African giant rat with Masson's Trichrome and Periodic Acid Schiff implies that it is rich in collagen which its negative reaction with Verhoeff stain shows that the zone is devoid of elastic fibers.

In conclusion the histology of the adrenal gland of the AGR is similar to those of other mammals with a few exceptions. The adrenal capsule, cortex and medulla are Periodic Acid Schiff positive implying that they were all rich in carbohydrate. The adrenal capsule, the zona glomerulosa and adrenal medulla were Masson Trichrome (MT) positive implying that they were rich in collagen unlike the zona fasiculata and zona reticularis which were MT negative. The adrenal capsule and zona glomerulosa were Verhoeff Stain positive while the other zones of the cortex and the medulla were negative.

OLUKOLE, S. G.; ADEAGBO, M. A. \& OKE, B. O. Histología e histoquímica de la glándula adrenal de la rata africana gigante (Cricetomys gambianus, Waterhouse). Int. J. Morphol., 34(4):14551460, 2016.

RESUMEN: La histología y la histoquímica de la glándula suprarrenal de la rata africana gigante (Cricetomys gambianus Waterhouse) (RGA) se llevó a cabo utilizando diez ratas macho adultas con el objetivo de proporcionar información que podría ser útil para un mejor conocimiento de la estructura y función de la glándula. La glándula suprarrenal de la rata africana gigante tiene una corteza y una médula distintas, rodeadas por un borde delgado de la cápsula. La corteza suprarrenal tiene tres zonas que son básicamente: zona glomerulosa, zona fasciculata y zona reticular, con ausencia de zona intermedia. La zona glomerulosa contiene células poliédricas que forman racimos irregulares o cuerdas, mientras que la zona fasciculata tenía células radiales de forma cuboidal o poliédrica. Las células de la zona reticular son similares a las de la zona fasciculata y además contienen células pequeñas como cordones irregulares y racimos. Las células de la médula suprarrenal están compuestas por células epitelioides irregulares dispuestas en grupos redondeados o cuerdas cortas y son en su mayoría células cromafines columnares o poliédricas, que están separadas por sinusoides. La cápsula suprarrenal y la médula suprarrenal fueron positivas con tricrómico de Masson, a diferencia de la zona fasciculata y la zona reticular. La cápsula suprarrenal y la zona glomerulosa fueron positivas a Verhoeff, a diferencia de las otras 
zonas de la glándula. En conclusión, la histología de la glándula suprarrenal de la RGA es similar a la de otros mamíferos con algunas excepciones; toda la glándula es rica en carbohidratos, mientras que la cápsula y por extensión, la parte más externa de la corteza, son ricas en colágeno y fibras elásticas. El resultado de esta investigación proporciona información necesaria para mejorar la comprensión de la estructura y función de la glándula suprarrenal del animal.

PALABRAS CLAVE: Glándula suprarrenal; Rata africana gigante; Corteza; Médula.

\section{REFERENCES}

Akinloye, A. K. \& Oke, B. O. Characterization of the uterus and mammary glands of the female african giant rats (Cricetomys gambianus, Waterhouse) in Nigeria. Int. J. Morphol., 28(1):936, 2010.

Bacha, W. J. \& Bacha, L. M. Color Atlas of Veterinary Histology. Philadelphia, Lippincott Williams \& Wilkins, 2000.

Banks, J. W. Applied Veterinary Histology. $3^{\text {rd }}$ ed. St. Louis, Mosby Year Book, 1993.

Clark, L. S.; Cowan, D. F. \& Pfeiffer, D. C. A morphological and histological examination of the pan-tropical spotted dolphin (Stenella attenuata) and the spinner dolphin (Stenella longirostris) adrenal gland. Anat. Histol. Embryol., 37(2):1539, 2008.

Dellmann, H. D. Textbook of Veterinary Histology. $4^{\text {th }}$ ed. Philadelphia, Lea \& Fabiger, 1993. pp.270-84.

Junqueira, L. C. \& Carneiro, J. Basic Histology. Textbook \& Atlas. $11^{\text {th }}$ ed. New York, Lange Medical Books McGraw-Hill, 2005.

Moore, K. L.; Dalley, A. F. \& Agur, A. M. R. Clinically Oriented Anatomy. $7^{\text {th }}$ ed. Philadelphia, Wolters Kluwer/Lippincott Williams \& Wilkins Health, 2014. pp.294-8.

Nzalak, J. O.; Onyeanusi, B. I., Samuel, A. O.; Ambrose, V. H. \& Ibe, C. S. Histological and histochemical studies of the colon in the African giant rat (Cricetomys gambianus, Waterhouse 1840). J. Vet. Anat., 4(1):1-10, 2011.

Nzalak, J. O.; Onyeanusi, B. I. \& Salami, S. O. Macrometric study of the digestive system of the African giant rat (Cricetomys gambianus, Waterhouse 1840). Eur. J. Anat., 16(2):113-8, 2012.

Oke, B.O. Some Aspects of Reproductive Biology of the Male African Giant Rat (Cricetomys gambianus, Waterhouse). $\mathrm{PhD}$ Thesis. Ibadan, University of Ibadan, 1988.

Oke, B. O. \& Aire, T. A. The bulbourethral (Cowper's gland) of the African giant rat (Cricetomys gambianus, Waterhouse). Vet. Arch., 59:267-74, 1989.
Oke, B. O. \& Aire, T. A. Ultrastructural evidence of secretion in different zones of the caput epididymis of the African giant rat (Cricetomys gambianus, Waterhouse). Vet. Arch., 60:207-12, 1990.

Olude, M. A.; Olopade, J. O.; Akinloye, A. K. \& Mustapha, O. A. Macro-anatomical investigations of the skeletons of the African giant rat (Cricetomys gambianus Waterhouse 1840) II: Fore limb. Eur. J. Anat., 14(1):19-23, 2010.

Onwuama, K. T.; Salami, S. O.; Sulaiman, M. H. \& Umosen, A. D. Macro-anatomical studies of the African giant pouched rat (Cricetomys gambianus) axial skeleton. Stand. Sci. Res. Essays, l(10):221-7, 2013.

Onyeanusi, B. I.; Adeniyi, A. A.; Ayo, J. O.; Ibe, C. S. \& Onyeanusi, C. G. A comparative study on the urinary system of the African giant rat (Cricetomys gambianus Waterhouse) and the Wistar rat. Pak. J. Nutr., 8(7):1043-7, 2009.

Vukovic, S.; Lucic, H.; Zivkovic, A.; Duras Gomercic, M.; Gomercic, T. \& Galov, A. Histological structure of the adrenal gland of the bottlenose dolphin (Tursiops truncatus) and the striped dolphin (Stenella coeruleoalba) from the Adriatic Sea. Anat. Histol. Embryol., 39(1):59-66, 2010.

Correspondence to:

Dr. S G. Olukole DVM, MVPH, MSc, PhD (Ibadan)

Post Doctoral Fellow (Anatomy)

Department of Anatomy and Physiology

Faculty of Veterinary Science

University Pretoria

SOUTH AFRICA

E-mail: Debo.Olukole@up.ac.za deborolukole@yahoo.com sg.olukole@mail.ui.edu.ng

Received: 30-10-2015

Accepted: 19-08-2016 